\title{
Comparative Study of Structure - Activity Relationship of Di and Triorganotin (IV) Complexes of Monomethyl Glutarate
}

\author{
Wajid Rehman $^{* a}$, Musa Kaleem Baloch ${ }^{a}$ and Amin Badshah ${ }^{b}$ \\ ${ }^{a}$ Department of Chemistry, Gomal University, Dera Ismail Khan, Pakistan \\ ${ }^{b}$ Department of Chemistry, Quaid-e-Azam University, Islamabad, Pakistan
}

\begin{abstract}
Uma série de complexos di- e tri-organoestanho(IV) de metilglutarato foram sintetizados e caracterizados por espectroscopia de $\mathrm{RMN}$ de ${ }^{1} \mathrm{H},{ }^{13} \mathrm{C}$ e ${ }^{119} \mathrm{Sn}$, no infravermelho e Mössbauer de ${ }^{119} \mathrm{Sn}$. Baseado nestas técnicas propõe-se que o ligante se encontra ligado ao estanho através do oxigênio da carbonila. Os dados revelam também que os complexos diorganoestanho(IV) são hexacoordenados, com geometria octaedrica, enquanto que os complexos triorganoestanho(IV) são pentacoordenados e possuem geometria bipiramidal trigonal. A avaliação biológica contra vários microorganismos indica que os complexos diorganoestanho(IV) são menos ativos que os triorganoestanho(IV).
\end{abstract}

A series of di and triorganotin(IV) complexes of monomethyl glutarate have been synthesized and characterized through ${ }^{1} \mathrm{H}{ }^{13} \mathrm{C}{ }^{119} \mathrm{Sn}$ NMR, FT-IR and ${ }^{119} \mathrm{Sn}$ Mössbauer spectroscopy. On the basis of these techniques, it is proposed that the ligand molecule is bound to the tin atom through the carbonyl oxygen. The data reveal that diorganotin(IV) complexes exhibit hexa-coordination with octahedral geometry, while triorganotin(IV) complexes have penta-coordination with trigonal bipyramidal geometry. Biological evaluation against various microorganisms indicate that diorganotin(IV) complexes are less active than the triorganotin(IV) complexes.

Keywords: organotin(IV), monomethyl glutarate, biological activity

\section{Introduction}

Organotin(IV) complexes have wide applications as catalysts, stabilizers as biocides, as antifouling agents, and for wood preservers. ${ }^{1-10}$ In recent years, investigations have been carried out to test their antitumor activity, and it has been observed that indeed several di and triorganotin(IV) species were found to be active against various types of cancer. ${ }^{11-13}$. Biological activity of organotin complexes is believed to be independent on the structure of molecule and coordination number of the metal. ${ }^{4-6}$ It has also been noted that many di and triorganotin(IV) carboxylates display interesting anti tumor activities. ${ }^{13-20}$ However the solubility of di and tri-organotin(IV) carboxylates in water and water-ethanol is poor, therefore many organotin(IV) complexes with carboxylate ligands containing polar subsitituents (hydroxo and oxo groups) have been prepared and studied. ${ }^{13-20}$ In a previous paper we described the synthesis of organotin(IV) complexes of maleimidoacetic

* e-mail: sono_waj@yahoo.com acid. ${ }^{21}$ In the present work we report the synthesis, spectroscopic characterization, antibacterial and various biological activities of a series of di and triorganotin(IV) complexes of monomethyl glutarate.

\section{Experimental}

All the di and triorganotin(IV) compounds except for dibenzyl and tribenzyl tin chlorides were purchased from Fluka and were used as such. Di and tribenzyltin chlorides were synthesized from the literature method. ${ }^{22}$ All the reactions were carried out under anhydrous and oxygen free nitrogen atmosphere. The solvents used were dried before use according to the literature method. ${ }^{23}$

The melting points were measured on a Reichert thermometer of F.G.Bode Co. Austria. IR spectra were obtained in KBr using a Perkin Elmer FT IR -1605 spectrophotometer. Elemental analyses were carried out on a Yanaco MT-3 high-speed CHN analyzer with an antipyrene as a reference compound. The ${ }^{1} \mathrm{H}-{ }^{13} \mathrm{C}$ - and ${ }^{119} \mathrm{Sn}$ NMR spectra were recorded on a multinuclear FT NMR 
$200 \mathrm{MHz}$ of JEOL using TMS as an internal standard. Some of the ${ }^{13} \mathrm{C}$ spectra were measured on a Bruker AM 270 instruments at $50 \mathrm{MHz}$ with ${ }^{13} \mathrm{C}$ probe. The Mössbauer spectra were recorded at $80 \mathrm{~K}$ on a Cryophysics instrument equipped with a $15 \mathrm{mCi} \mathrm{Ca}{ }^{119} \mathrm{SnO}_{3}$ source.

\section{Syntheses}

Ligand $(H L)$. Glutaric anhydride $(50 \mathrm{mmol})$ was refluxed in excess of dry methanol for $10 \mathrm{~h}$ under anhydrous conditions; excess of solvent was removed under reduced pressure, resulting in a yellow liquid.

Synthesis of dimethyl, diethyl, diphenyl, and dibenzyltin complexes of monomethyl glutarate (1-5). The monomethyl glutarate $(10 \mathrm{mmol})$ was dissolved in a minimum amount of methanol $(25 \mathrm{~mL})$. To this triethyl amine $(10 \mathrm{mmol})$ was added and the reaction was refluxed for 10-30 min. A hot methanolic solution of diethyl, dimethyl, diphenyl, or dibenzyltin dichloride $(5 \mathrm{mmol})$ was added to the above reaction mixture, this mixture was refluxed for 7-8 $\mathrm{h}$ under nitrogen. The reaction mixture was centrifuged and filtered to remove the triethylamine chloride; any excess of solvent was removed under reduced pressure. Liquid complexes are formed for diethyl and dimethyltin dichlorides, while diphenyl and dibenzyltin dichlorides are amorphous solids, which were recrystallized from a 1:2(v/v) mixture of methanol and petroleum ether (b.p. $40-60{ }^{\circ} \mathrm{C}$ ).

Synthesis of dibutyltin complex of monomethyl glutarate (3). The complex was prepared under anhydrous conditions by drop wise addition of dry, hot benzenemethanolic $(3: 1 \mathrm{v} / \mathrm{v}, 100 \mathrm{~mL})$ solution of dibutyltin oxide (4 mmol) to a hot methanolic solution of monomethyl glutarate ( $8 \mathrm{mmol})$. The mixture was refluxed with constant stirring giving a clear solution after $30 \mathrm{~min}$; refluxing was continued for 8-9 $\mathrm{h}$ with azeotropic removal of water. Any excess of solvent was removed under reduced pressure; liquid complex was obtained as an end product.

Synthesis of trimethyl, tributyl triphenyl, and tribenzyl tin complexes of monomethyl glutarate (6-9). The monomethyl glutarate $(5 \mathrm{mmol})$ was dissolved in a minimum amount of methanol $(25 \mathrm{~mL})$. To this triethylamine ( $5 \mathrm{mmol}$ ) was added and the reaction was refluxed for 10-30 min. A hot methanolic solution of trimethyl, triphenyl, or tribenzyl tin chloride (5mmol) was added to the above reaction mixture, this mixture was again refluxed for $8-9 \mathrm{~h}$ under nitrogen. The reaction mixture was centrifuged and filtered to remove the triethylamine chloride; excess solvent was removed under reduced pressure. Oily complexes are formed for trimethyl and tributyltin chloride, while solid complexes are obtained for triphenyl and tribenzyl tin complexes, which were re-crystallized from a 1:2(v/v) mixture of methanol and petroleum ether (b.p. $40-60{ }^{\circ} \mathrm{C}$ ).

\section{Antibacterial activity}

The antibacterial activity was determined by using the agar well diffusion method. ${ }^{24}$ The wells were dug in the media with a sterile borer and an eight-hour-old bacterial inoculums containing ca. $10^{4}-10^{6}$ colony-forming units $(\mathrm{CFU}) / \mathrm{mL}$ was spread on the surface of the nutrient agar using a sterile cotton swab. The recommended concentration of the test sample ( $2 \mathrm{mg} / \mathrm{mL}$ in DMSO) was introduced into the respective wells. Other wells containing DMSO and the reference antibacterial drug served as negative and positive controls, respectively. The plates were incubated immediately at $37^{\circ} \mathrm{C}$ for $20 \mathrm{~h}$. The activity was determined by measuring the diameter of the inhibition zone (in $\mathrm{mm}$ ) showing complete inhibition. Growth inhibition was calculated with reference to the positive control.

\section{Anti-inflammatory activity}

A freshly prepared suspension of carrageenin $(0.2 \mathrm{~mL}$, $1.0 \%$ in $0.9 \%$ saline) was injected subcutaneously into the plantar aponeurosis of the hind paw of the rats of both sexes (body weight 120/160 g) by the method of Winter $e t$ $a l .{ }^{25}$ One group of five rats was kept as a control and the animals of the other group of five, each was pretreated with the test drugs given orally $30 \mathrm{~min}$ before the carrageenin injection. The paw volume was measured by a water plethysmometer socrel at the time of treatment and then at an interval of $1 \mathrm{~h}$ for $4 \mathrm{~h}$. The mean increase of the paw volume at each time interval was compared with that of the control group (five rats treated with carrageenin, but not treated with test compounds and per cent antiinflammatory value was calculated as given below:

$\%$ Anti-inflammatory $=(1-$ DT/ DC $) \times 100$

where, DT and DC are the volumes of paw edema in drug treated and control groups, respectively.

\section{Acute toxicity study}

ALD50 (average lethal dose at 50\% survival) of the compounds was determined in albino mice. The mice of either sex (body weight 20-25 g) were used. The test compound was injected intraperitoneally at different dose levels in groups of 10 animals and percent mortality in each group was observed after $24 \mathrm{~h}$ of drug administration. 
The ALD50 value $\left(1 \mathrm{mg} \mathrm{kg}^{-1}\right)$ was calculated from the data obtained by the method of Smith. ${ }^{26}$

\section{Cytostatic activity}

Cytostatic activity was assayed against the established cell line $\mathrm{KB}$, which derives from a human oral epidermoid carcinoma. Stock cultures were grown in $25 \mathrm{~cm}^{3}$ flasks containing $10 \mathrm{~mL}$ of buffered Eagle's Minimum Essential Medium (MEM) supplemented with glutamine, non essential amino acids $(1 \%)$ and new born calf serum $(10 \%)$, according to the literature. ${ }^{27}$ The cell population doubling time was approximately $24 \mathrm{~h}$. The cells were dissociated with $0.05 \%$ trypsin solution, plated at density of $5 \times 10^{5}$ cells per well in 24-well cell culture clusters (Costar) containing $1.0 \mathrm{~mL}$ of MEM per well, and preincubated for $24 \mathrm{~h}$ to allow adhesion to the substrate. Subsequently, the compounds to be tested were dissolved immediately before use in DMSO and these solutions were diluted with the growth medium to the desired concentrations before addition to the wells. At least five concentrations of each compound were used, with eight cell culture wells for each concentration. Each compound was assayed on at least three separate occasions. Each assay included a blank containing complete medium without cells. The cells were incubated with the compounds to be tested at $37{ }^{\circ} \mathrm{C}$ in an atmosphere that was $5 \% \mathrm{CO}_{2}$ and had a relative humidity of $100 \%$. The incubation time was $72 \mathrm{~h}$, during which period the control cells showed exponential growth.

Cells growth was terminated by in situ fixation and followed by staining with the protein-binding dye sulforhodamine B (SRB). ${ }^{28}$ Specifically, adherent cell cultures were fixed in situ by addition of $250 \mu \mathrm{L}$ of cold $50 \%(\mathrm{~m} / \mathrm{v})$ trichloroacetic acid (TCA) and were kept for $60 \mathrm{~min}$ at $4{ }^{\circ} \mathrm{C}$. The supernatant was then discarded and the plates were washed three times with deionised water and dried. SRB solution $(500 \mu \mathrm{L}, 0.4 \% \mathrm{~m} / \mathrm{v}$ in $1 \% \mathrm{AcOH})$ was added to each well, and the cells were allowed to stain for 20-30 $\mathrm{min}$ at room temperature. Unbound SRB was removed by washing three times with $1 \% \mathrm{AcOH}$, and the plates were then air dried while bound stain was solubilized with unbuffered Tris base [tris(hydoxymethyl)aminomethane]. Optical densities at $565 \mathrm{~nm}$ were read on a Perkin- Elmer 550 SE spectrophotometer.

Cytostatic activity was evaluated from the inhibition of cell growth in the treated cultures with respect to the controls. $\mathrm{IC}_{50}$, the concentration of the test compound at which cell proliferation was $50 \%$ of that observed in control cultures, was determined by linear regression analysis. The statistical significance of these results was estimated by means of Student's t-test $(\mathrm{P}<0.01)$.

\section{Results and Discussion}

Reactions of $\mathrm{R}_{2} \mathrm{SnCl}_{2}$ and $\mathrm{R}_{3} \mathrm{SnCl}$ with monomethyl glutarate and triethylamine in 1:2 molar ratios respectively, led to the formation of complexes according to equations $1-3$.

The above reactions were found to be quite facile and were complete within 8-9 $\mathrm{h}$ of refluxing. The resulting solid or liquid complexes were obtained in good yields (70-90 $\%$ ). The solid complexes were soluble in methanol, chloroform, DMSO and DMF. Satisfactory elemental analysis (Table 1) has been obtained for all the complexes. Structural proposals are based on FT-IR, ${ }^{1} \mathrm{H}$ NMR, ${ }^{13} \mathrm{C}$ NMR, ${ }^{119} \mathrm{Sn}$ and Mössbauer studies. The results obtained through these techniques are in agreement with the proposed 1:1 and 1:2 stoichometry between the organotin moiety and the ligand.

$$
\begin{aligned}
& \mathrm{R}_{2} \mathrm{SnCl}_{2}+2 \mathrm{~L}+2 \mathrm{Et}_{3} \mathrm{~N} \rightarrow \mathrm{R}_{2} \mathrm{SnL}_{2}+2 \mathrm{Et}_{3} \mathrm{~N} \cdot \mathrm{HCl} \\
& \mathrm{R}=\text { methyl, ethyl, phenyl and benzyl } \\
& { }^{\mathrm{n}} \mathrm{Bu}_{2} \mathrm{SnO}+2 \mathrm{~L} \rightarrow{ }^{\mathrm{n}} \mathrm{Bu}_{2} \mathrm{SnL}_{2}+2 \mathrm{H}_{2} \mathrm{O} \\
& \mathrm{R}_{3} \mathrm{SnCl}+\mathrm{L}+\mathrm{Et}_{3} \mathrm{~N} \rightarrow \mathrm{R}_{3} \mathrm{SnL}+\mathrm{Et}_{3} \mathrm{~N} \cdot \mathrm{HCl} \\
& \mathrm{R}=\text { methyl, butyl, phenyl and benzyl }
\end{aligned}
$$

\begin{tabular}{|c|c|c|c|c|c|c|c|}
\hline \multirow{2}{*}{$\begin{array}{l}\text { Molecular } \\
\text { formula }\end{array}$} & \multirow{2}{*}{$\begin{array}{l}\text { Molecular } \\
\text { weight }\end{array}$} & \multirow{2}{*}{$\begin{array}{l}\mathrm{m} \cdot \mathrm{p} . \\
\left({ }^{\circ} \mathrm{C}\right)\end{array}$} & \multirow{2}{*}{$\begin{array}{l}\text { Yield } \\
(\%)\end{array}$} & \multirow{2}{*}{$\begin{array}{l}\text { Recrystallization } \\
\text { solvent }\end{array}$} & \multicolumn{3}{|c|}{ Elemental Analysis Found (Calc.) / (\%) } \\
\hline & & & & & $\mathrm{C}$ & $\mathrm{H}$ & $\mathrm{Sn}$ \\
\hline $\mathrm{C}_{6} \mathrm{H}_{10} \mathrm{O}_{4}(\mathrm{HL})$ & 146 & liquid & 70 & - & $49.29(49.31)$ & $6.82(6.84)$ & - \\
\hline $\mathrm{C}_{14}^{6} \mathrm{H}_{24} \mathrm{O}_{8}^{4} \mathrm{Sn}(\mathbf{1})$ & 440 & liquid & 78 & - & $38.16(38.18)$ & $5.43(5.45)$ & $27.26(27.27)$ \\
\hline $\mathrm{C}_{16} \mathrm{H}_{28} \mathrm{O}_{8} \mathrm{Sn}(2)$ & 468 & liquid & 75 & - & $40.99(41.02)$ & $5.96(5.98)$ & $25.62(25.64)$ \\
\hline $\mathrm{C}_{20} \mathrm{H}_{36} \mathrm{O}_{8} \mathrm{Sn}(3)$ & 524 & liquid & 72 & - & $45.78(45.80)$ & $6.86(4.96)$ & $22.87(22.90)$ \\
\hline $\mathrm{C}_{22}^{20^{-}} \mathrm{H}_{28} \mathrm{O}_{8} \mathrm{Sn}(4)$ & 540 & 105 & 75 & Chloroform & $58.64(58.66)$ & $5.15(5.18)$ & $22.20(22.22)$ \\
\hline $\mathrm{C}_{26}^{22} \mathrm{H}_{32}^{28} \mathrm{O}_{8}^{8} \mathrm{Sn}(\mathbf{5})$ & 592 & 95 & 70 & Chloroform & $52.67(52.70)$ & $5.38(5.40)$ & $20.26(20.27)$ \\
\hline $\mathrm{C}_{9} \mathrm{H}_{18} \mathrm{O}_{4}^{8} \mathrm{Sn} \quad(6)$ & 310 & liquid & 90 & - & $34.80(34.83)$ & $5.79(5.80)$ & $38.68(38.70)$ \\
\hline $\mathrm{C}_{18} \mathrm{H}_{36} \mathrm{O}_{4} \mathrm{Sn}(7)$ & 436 & liquid & 80 & - & $49.52(49.54)$ & $8.23(8.20)$ & $27.99(27.52)$ \\
\hline $\mathrm{C}_{21} \mathrm{H}_{24} \mathrm{O}_{4} \mathrm{Sn}(\mathbf{8})$ & 460 & 107 & 85 & Chloroform & $54.75(54.78)$ & $5.19(5.21)$ & $25.97(26.08)$ \\
\hline $\mathrm{C}_{16} \mathrm{H}_{28} \mathrm{O}_{8} \mathrm{Sn}(\mathbf{9})$ & 538 & 121 & 80 & Ethanol & $60.20(60.22)$ & $5.55(5.57)$ & $22.27(22.30)$ \\
\hline
\end{tabular}

Table 1. Characteristic properties of di and triorganotin(IV) complexes of monomethyl glutarate 


\section{Infrared spectral studies}

The characteristic infrared absorption frequencies (in $\mathrm{cm}^{-1}$ ) and their assignments for the ligand and their organotin(IV) complexes are given in Table 2.

Infrared OCO stretching frequencies have been utilized to distinguish coordinated from non-coordinated carboxyl groups, and also, to identify the nature of bonding of carboxylic group, viz., monodentate or bridging. The carboxylate groups in the organotin (IV) derivatives generally adopt a bridged structure in the solid state unless the organic substituents at tin are bulky or unless the carboxylate group is branched at the $\alpha$-carbon. ${ }^{27}$ The complexation of tin(IV) with the ligand is confirmed by the presence of $\mathrm{Sn}-\mathrm{O}$ and $\mathrm{Sn}-\mathrm{C}$ bonds in the range of 545$578 \mathrm{~cm}^{-1}$ and $525-555 \mathrm{~cm}^{-1} \cdot{ }^{29-30}$ Coordination of the complexes was based on the $\Delta v$ difference between $(\mathrm{COO})_{\text {sym }}$ and (COO) $)_{\text {asym }}$ and on the corresponding band position; it is proposed that the carboxylate group acts as a bidentate ligand in all these complexes. ${ }^{31}$ According to Lebl et al. ${ }^{31}$ the values of $\Delta v\left[\Delta v=\left(v_{\text {asym }}-v_{\text {sym }}\right)\right.$ can be divided into three groups: $(i)$ in compounds where $\Delta v(\mathrm{COO})>350$, hence these compounds contain, with high probability, the monodentate carboxylate group. However, other very weak intra- and intermolecular interactions cannot be excluded; (ii) when $\Delta v(\mathrm{COO})<200$, the carboxylate groups of these compounds can be considered bidentate; (iii) compounds where $\Delta v(\mathrm{COO})<350$ and $>200$ contain the carboxylate groups in an intermediate state between monodentate and bidentate, which is called anisobidentate. The $\mathrm{C}=\mathrm{O}$ stretching frequencies were also observed at $1720-1735 \mathrm{~cm}^{-1}$.

\section{${ }^{1} H$ NMR spectral analysis}

The characteristic resonance peaks in the ${ }^{1} \mathrm{H}$ NMR spectra of the complexes, recorded in $\mathrm{CDCl}_{3}$, are given in Table 3. A broad resonance at $\delta 11.5$ in the spectrum of the ligand due to the carboxylic proton is absent in the spectra of the complexes, indicating the involvement of the carboxylic oxygen in bonding to tin. According to the earlier reported work, ${ }^{32}$ the magnetically nonequivalent alkyl protons of the ligands undergo diamagnetic shielding upon complexation. This is probably due to the conformation, which the ligand molecule may adopt upon complexation. The protons in the complexes have been identified and the total number of protons calculated from the integration curves are in agreement with the proposed molecular formulae.

Table 2. Characteristic properties of di and triorganotin(IV) complexes of monomethyl glutarate

\begin{tabular}{llllllll}
\hline Compound & $v(\mathrm{COO})_{\text {asym }}$ & $v(\mathrm{COO})_{\text {sym }}$ & $\Delta v$ & $v \mathrm{C}=\mathrm{O}$ & $v \mathrm{COOH}$ & $v \mathrm{Sn}-\mathrm{C}$ & $v \mathrm{Sn}-\mathrm{O}$ \\
\hline $\mathrm{HL}$ & - & - & - & $1720 \mathrm{~s}$ & $2065 \mathrm{~m}$ & - & - \\
$\mathbf{1}$ & $1620 \mathrm{~s}$ & $1445 \mathrm{~s}$ & 185 & $1735 \mathrm{~s}$ & $\mathrm{~A}$ & $530 \mathrm{~m}$ & $560 \mathrm{~m}$ \\
$\mathbf{2}$ & $1630 \mathrm{~s}$ & $1470 \mathrm{~m}$ & 160 & $1725 \mathrm{~m}$ & $\mathrm{~A}$ & 525 & $545 \mathrm{~m}$ \\
$\mathbf{3}$ & $1640 \mathrm{~s}$ & $1465 \mathrm{br}$ & 175 & $1722 \mathrm{~s}$ & $\mathrm{~A}$ & $554 \mathrm{~m}$ & $570 \mathrm{~m}$ \\
$\mathbf{4}$ & $1635 \mathrm{~s}$ & $1475 \mathrm{~m}$ & 160 & $1715 \mathrm{~s}$ & $\mathrm{~A}$ & $532 \mathrm{br}$ & $564 \mathrm{~m}$ \\
$\mathbf{5}$ & $1650 \mathrm{~s}$ & $1482 \mathrm{~s}$ & 178 & $1733 \mathrm{~s}$ & $\mathrm{~A}$ & $555 \mathrm{w}$ & $578 \mathrm{~m}$ \\
$\mathbf{6}$ & $1630 \mathrm{~s}$ & $1454 \mathrm{~s}$ & 176 & $1722 \mathrm{~m}$ & $\mathrm{~A}$ & $520 \mathrm{~m}$ & $566 \mathrm{~m}$ \\
$\mathbf{7}$ & $1642 \mathrm{~s}$ & $1440 \mathrm{~m}$ & 194 & $1730 \mathrm{~m}$ & $\mathrm{~A}$ & $547 \mathrm{br}$ & $572 \mathrm{w}$ \\
$\mathbf{8}$ & $1638 \mathrm{~s}$ & $1454 \mathrm{br}$ & 184 & $1720 \mathrm{~m}$ & $\mathrm{~A}$ & $540 \mathrm{~m}$ & $563 \mathrm{~m}$ \\
$\mathbf{9}$ & $1632 \mathrm{~s}$ & $1460 \mathrm{~s}$ & 172 & $1722 \mathrm{~s}$ & $\mathrm{~A}$ & $522 \mathrm{~m}$ & $560 \mathrm{~m}$ \\
\hline
\end{tabular}

$\mathrm{s}=$ strong; $\mathrm{m}=$ medium; $\mathrm{w}=$ weak $; \mathrm{br}=$ broad $\mathrm{A}=$ absent.

Table 3. ${ }^{1} \mathrm{H}$ NMR spectral data of the di and tri-organotin(IV) complexes

\begin{tabular}{|c|c|c|c|c|c|c|c|c|c|c|}
\hline Proton & $\mathrm{HL}$ & 1 & 2 & 3 & 4 & 5 & 6 & 7 & 8 & 9 \\
\hline 1 & $3.5 \mathrm{~s}$ & $3.2 \mathrm{~s}$ & $3.4 \mathrm{~s}$ & $3.6 \mathrm{~s}$ & $3.6 \mathrm{~s}$ & $3.5 \mathrm{~s}$ & $3.2 \mathrm{~s}$ & $3.3 \mathrm{~s}$ & $3.6 \mathrm{~s}$ & $3.5 \mathrm{~s}$ \\
\hline 2 & - & - & - & - & - & - & - & - & - & - \\
\hline 3 & $2.3 \mathrm{t}$ & $2.4 \mathrm{t}$ & $2.4 \mathrm{t}$ & $2.5 \mathrm{t}$ & $2.6 \mathrm{t}$ & $2.5 \mathrm{t}$ & $2.4 \mathrm{t}$ & $2.4 \mathrm{t}$ & $2.7 \mathrm{t}$ & $2.5 \mathrm{t}$ \\
\hline 4 & $1.9 \mathrm{q}$ & $2.1 \mathrm{q}$ & $2.1 \mathrm{q}$ & $2.3 \mathrm{q}$ & $2.5 \mathrm{q}$ & $2.3 \mathrm{q}$ & $2.2 \mathrm{q}$ & $2.2 \mathrm{q}$ & $2.6 \mathrm{q}$ & $2.4 \mathrm{q}$ \\
\hline 5 & $2.3 \mathrm{t}$ & $2.3 \mathrm{t}$ & $2.5 \mathrm{t}$ & $2.5 \mathrm{t}$ & $2.6 \mathrm{t}$ & $2.4 \mathrm{t}$ & $2.3 \mathrm{t}$ & $2.6 \mathrm{t}$ & $2.6 \mathrm{t}$ & $2.4 \mathrm{t}$ \\
\hline 6 & $11.2 \mathrm{~s}$ & A & $\mathrm{A}$ & A & A & $\mathrm{A}$ & A & A & A & A \\
\hline$\alpha$ & - & $0.6 \mathrm{~s}$ & $1.3 \mathrm{t}$ & $0.9 \mathrm{t}$ & $2.6 \mathrm{~m}$ & $2.2 \mathrm{~s}$ & $0.5 \mathrm{~s}$ & $0.5 \mathrm{~m}$ & $7.8 \mathrm{~m}$ & $2.1 \mathrm{~s}$ \\
\hline$\beta$ & - & - & $2.2 \mathrm{q}$ & $1.2 \mathrm{~m}$ & $7.7 \mathrm{~m}$ & $7.8 \mathrm{~m}$ & - & $1.3 \mathrm{~m}$ & $7.6 \mathrm{~m}$ & $7.7 \mathrm{~m}$ \\
\hline$\gamma$ & - & - & - & $1.3 \mathrm{~m}$ & $7.7 \mathrm{~m}$ & $7.8 \mathrm{~m}$ & - & - & $7.7 \mathrm{~m}$ & $7.7 \mathrm{~m}$ \\
\hline$\delta$ & - & - & - & - & - & $7.9 \mathrm{~m}$ & - & - & $7.8 \mathrm{~m}$ & $7.7 \mathrm{~m}$ \\
\hline$\omega$ & - & - & - & - & - & - & - & - & - & $7.8 \mathrm{~m}$ \\
\hline
\end{tabular}

$\mathrm{s}=$ singlet $; \mathrm{t}=$ triplet $\mathrm{q}=$ quintet $; \mathrm{m}=$ multiplet; $\mathrm{A}=$ absent. 
<smiles>COC(=O)CCCC(=O)O</smiles>

Proposed structure for the ligand<smiles>[R][N+]1([R])OC(CCCC(=O)OC)O1</smiles><smiles>[R][Sn]([R])(OC(=O)CCCC(=O)OC)OC(=O)CCCC(=O)OC</smiles>

where $\mathrm{R}=-\mathrm{CH}_{3}, \mathrm{CH}_{3} \mathrm{CH}_{2} \mathrm{CH}_{2} \mathrm{CH}_{2}-$<smiles></smiles>

Proposed structure for the di and triorganotin(IV) complexes

${ }^{13} \mathrm{C}$ NMR spectral studies

${ }^{13} \mathrm{C}$ NMR spectra of the free ligand and of the complexes were recorded in $\mathrm{CDCl}_{3}$; the most informative data regard the chemical shift of the-COO ligand carbon atom (Table 4). The deshielding with the same signal of free ligand is indicative of coordination through carbonyl oxygen atom in all of the complexes, which leads to a electron density on the carboxylic carbon. ${ }^{33}$ Coordination of the tin atom in organotins has been related to ${ }^{1} J\left({ }^{119} \mathrm{Sn}-\right.$ ${ }^{13} \mathrm{C}$ ) coupling constants. The ${ }^{1} J\left({ }^{119} \mathrm{Sn}-{ }^{13} \mathrm{C}\right)$ coupling constant values obtained for the synthesized complexes are indicative of penta and hexa coordination for tri and diorganotin(IV) compounds respectively. ${ }^{33}$ The carbons of phenyl and alkyl groups attached to tin are observed at positions comparable with other, similar compounds. ${ }^{34,35}$
${ }^{119} \mathrm{Sn}$ spectra

${ }^{119} \mathrm{Sn}$ chemical shift of organotin(IV) compounds cover a range of 600ppm. The experimental data (Table 4) shows a significant shift of the resonance peaks to lower frequencies in moving from the starting organotin(IV) reagents to the $1: 1$ and 1:2 adducts, as reported for the analogous organotin(IV) derivatives..$^{36-39}$

These results are in agreement with the hypothesis of an increase in the coordination number of the tin atom in the complexes and, hence, of tin nuclear shielding. ${ }^{36-39}$

\section{${ }^{119} \mathrm{Sn}$ Mössbauer spectra}

The Mössbauer spectral parameters of all the compounds synthesized are summarized in Table 5. The isomer shifts and line widths of the complexes are typical of single tin(IV)

Table 4. ${ }^{13} \mathrm{C}$ and ${ }^{119} \mathrm{Sn}$ spectral data for di and triorganotin(IV) complexes

\begin{tabular}{|c|c|c|c|c|c|c|c|c|c|c|}
\hline Carbon & HL & 1 & 2 & 3 & 4 & 5 & 6 & 7 & 8 & 9 \\
\hline 1 & 51.9 & 51.9 & 52.0 & 52.2 & 52.4 & 52.3 & 51.9 & 52.1 & 52.3 & 52.2 \\
\hline 2 & 173.8 & 174.2 & 173.9 & 174.3 & 174.8 & 173.9 & 173.8 & 174.1 & 174.5 & 174.7 \\
\hline 3 & 31.8 & 31.8 & 31.9 & 32.1 & 32.3 & 31.9 & 31.9 & 31.9 & 32.3 & 31.7 \\
\hline 4 & 20.5 & 20.6 & 20.7 & 20.7 & 20.9 & 20.6 & 20.6 & 20.8 & 21.2 & 20.6 \\
\hline 5 & 31.5 & 31.8 & 31.7 & 31.9 & 32.1 & 31.8 & 31.5 & 31.2 & 31.6 & 32.2 \\
\hline 6 & 177.2 & 177.2 & 177.4 & 177.6 & 177.8 & 175.1 & 177.1 & 177.6 & 177.9 & 177.5 \\
\hline \multirow[t]{2}{*}{$\alpha$} & - & -2.1 & 1.35 & 24.5 & 136.5 & 25.9 & -2.5 & 20.7 & 137.5 & 29.6 \\
\hline & & [752.5] & {$[760]$} & {$[770.5]$} & [820.5] & [788] & {$[555.5]$} & {$[560]$} & [690] & {$[570]$} \\
\hline \multirow[t]{2}{*}{$\beta$} & - & - & 14.9 & 27.5 & 134.3 & 131.7 & - & 25.3 & 126.3 & 134.3 \\
\hline & & & [20] & [15] & {$[25]$} & [22] & & [18] & [22] & [20] \\
\hline \multirow[t]{2}{*}{$\gamma$} & - & - & - & 26.5 & 129.1 & 129.6 & - & 26.2 & 130.7 & 128.5 \\
\hline & & & & [58] & [61.5] & [55.7] & & [59.3] & [62.5] & [57.2] \\
\hline \multirow[t]{2}{*}{$\delta$} & - & - & - & 14.2 & 129.0 & 120.3 & - & 13.8 & 129.2 & 126.7 \\
\hline & & & & n.o & n.o & n.o & & n.o & n.o & n.o \\
\hline$\omega$ & - & - & - & - & - & 126.6 & - & - & - & 123.5 \\
\hline $\mathrm{Sn}^{119}$ & - & -350.5 & -330 & -310.5 & -250.5 & -320 & -240.5 & -171 & -98.5 & -150.5 \\
\hline
\end{tabular}

${ }^{\mathrm{n}} J\left[{ }^{19} \mathrm{Sn}-{ }^{13} \mathrm{C}\right]$ values are given in parenthesis, n.o $=$ not observed. 
site. ${ }^{40}$ A comparison between the quadrupole splitting data for organotin(IV) derivatives and those reported in the literature for analogous compounds, ${ }^{41}$ leads to the conclusion that, diorganotin(IV) complexes show hexa-coordination, ${ }^{42}$ while the triorganotin(IV) adducts show penta-coordination. ${ }^{43}$

\section{Biological studies}

Antibacterial activity. Antibacterial activity was performed against two Gram positive (Bacillus subtilis, Staphlococcus aureus) and 4 Gram-negative (Escherichia

Table 5. $\mathrm{Sn}^{119}$ - Mössbauer data of the di and triorganotin(IV) complexes

\begin{tabular}{lcccc}
\hline compound & Is & QS & $\Gamma_{1}$ & $\Gamma_{2}$ \\
\hline $\mathbf{1}$ & $1.30 \pm 0.01$ & $3.79 \pm 0.05$ & 0.95 & 1.08 \\
$\mathbf{2}$ & $1.27 \pm 0.03$ & $3.77 \pm 0.01$ & 0.87 & 1.01 \\
$\mathbf{3}$ & $1.46 \pm 0.05$ & $3.91 \pm 0.03$ & 1.15 & 1.25 \\
$\mathbf{4}$ & $1.13 \pm 0.01$ & $3.22 \pm 0.05$ & 0.19 & 0.95 \\
$\mathbf{5}$ & $1.52 \pm 0.05$ & $3.73 \pm 0.01$ & 0.89 & 0.92 \\
$\mathbf{6}$ & $1.28 \pm 0.03$ & $3.78 \pm 0.01$ & 1.10 & 1.12 \\
$\mathbf{7}$ & $1.43 \pm 0.01$ & $3.90 \pm 0.05$ & 0.96 & 0.98 \\
$\mathbf{8}$ & $1.22 \pm 0.01$ & $3.15 \pm 0.05$ & 1.36 & 1.41 \\
$\mathbf{9}$ & $1.41 \pm 0.05$ & $3.89 \pm 0.01$ & 0.88 & 0.86 \\
\hline
\end{tabular}

$\overline{\mathrm{Qs}}=$ quadrupole splitting; Is $=$ isomer shift; $\Gamma_{1}$ and $\Gamma_{2}=$ line widths. coli, Schigella flexenari, Pseudomonas aeruginosa, Salmonella typh) bacteria and the results are summarized in Table 6. In order to compare the results obtained, Imipinem is used as standard drug. It is concluded that the synthesized compounds showed higher activity than the monomethyl glutarate, but lower activity than the standard drug.

Anti-inflammatory activity. The anti-inflammatory activity (\% inhibition) of the synthesized complexes was conducted on adult albino rats (body weight 120- $160 \mathrm{~g}$ ) of Froster Charles species against carrageenin-induced edema in the doses of $50 \mathrm{mg} \mathrm{kg}^{-1}$ given orally and the acute toxicity (ALD50) was studied on albino mice (body weight 20- $25 \mathrm{~g}$ ) of either sex. The results are presented in Table 7 . The activity of the standard drug, phenyl butazone, is used for the comparison.

The studies on structure/activity correlation of organotin(IV) compounds reveal that the following structural features characterize the active compounds: ( $i$ ) the availability of coordination positions at tin; (ii) the occurrence of relatively stable ligand- Sn bond viz., Sn-O bond.

Among the diorganotin(IV) and triorganotin(IV) complexes, as revealed from the data given in Table 7 , the di and triphenyltin(IV) complexes are found to be more active than the others. The anti-inflammatory

Table 6. Anti bacterial bioassay results ${ }^{a, b, c, d}$ for $\mathrm{R}_{2} \mathrm{SnL}_{2}$ and $\mathrm{R}_{3} \mathrm{SnL}$ (Inhibition zone in $\mathrm{mm}$ )

\begin{tabular}{|c|c|c|c|c|c|c|c|c|c|c|c|}
\hline Micro-organism & Ligand & 1 & 2 & 3 & 4 & 5 & 6 & 7 & 8 & 9 & Standard Drug \\
\hline \multicolumn{12}{|l|}{ Gram- Positive } \\
\hline Bacillus subtills & 15 & 18 & 22 & 20 & 25 & 24 & 22 & 22 & 28 & 24 & 31 \\
\hline Staphlococcus aureus & 16 & na & 20 & 20 & 24 & 26 & 22 & 28 & 32 & 20 & 43 \\
\hline \multicolumn{12}{|l|}{ Gram-negative } \\
\hline Escherichia coli & $\mathrm{na}$ & 18 & 24 & 22 & 25 & na & 20 & 22 & 26 & na & 30 \\
\hline Schigella flexenari & na & na & na & na & 22 & na & 13 & na & 28 & na & 33 \\
\hline Pseudomonas aeruginosa & 12 & 14 & 12 & 16 & 20 & 16 & 14 & 14 & 22 & 18 & 25 \\
\hline Salmonella typh & na & 18 & 18 & 16 & 30 & 22 & 20 & 22 & 34 & 20 & 41 \\
\hline
\end{tabular}

${ }^{\mathrm{a}}$ Concentration.used: $1.00 \mathrm{mg} / 1.00 \mathrm{~mL}$ of DMSO; ${ }^{\mathrm{b}}$ size of well: $6 \mathrm{~mm}$ (diameter); ${ }^{\mathrm{c}}$ Standard drug: Imipinem; ${ }^{\mathrm{d}}$ na: no activity.

Table 7. ALD50 (in $\mathrm{mg} \mathrm{kg}^{-1}$ ) anti-inflammatory activity of di and triorganotin (IV) complexes

\begin{tabular}{lcc}
\hline Compound & $\begin{array}{c}\text { ALD50 } \\
\mathrm{mg} \mathrm{kg}^{-1}\end{array}$ & $\begin{array}{c}\text { Anti-inflammatory activity } \\
(1 \text { inhibition }) 50 \mathrm{mg} / \mathrm{kg} \text { po }\end{array}$ \\
\hline *Phenyl butazone & - & 38.4 \\
Ligand & $<400$ & 15.5 \\
$\mathbf{1}$ & $>500$ & 15.4 \\
$\mathbf{2}$ & $>500$ & 17.5 \\
$\mathbf{3}$ & $>500$ & 19.7 \\
$\mathbf{4}$ & $>500$ & 30.2 \\
$\mathbf{5}$ & $>500$ & 28.5 \\
$\mathbf{6}$ & $>500$ & 18.1 \\
$\mathbf{7}$ & $>500$ & 17.6 \\
$\mathbf{8}$ & $>400$ & 42.2 \\
$\mathbf{9}$ & $>400$ & 33.7 \\
\hline
\end{tabular}

*Standard drug
Table 8. Results of in vitro cytostatic assay against cell line KB

\begin{tabular}{|c|c|c|}
\hline Compound & $\mathrm{IC}_{50}\left(\mu \mathrm{g} \mathrm{mL}^{-1}\right.$ medium $)$ & $\mathrm{IC}_{50}(\mu \mathrm{M})$ \\
\hline Ligand & 0.10 & 0.24 \\
\hline 1 & 0.22 & 0.68 \\
\hline 2 & 3.32 & 6.54 \\
\hline 3 & 0.15 & 0.35 \\
\hline 4 & 0.34 & 0.62 \\
\hline 5 & 0.18 & 0.33 \\
\hline 6 & 0.39 & 0.66 \\
\hline 7 & 0.16 & 0.32 \\
\hline 8 & 0.35 & 0.68 \\
\hline 9 & 0.18 & 0.30 \\
\hline$*$ cis $-\left[\mathrm{PtCl}_{2}\left(\mathrm{NH}_{3}\right)_{2}\right]$ & 0.11 & 0.37 \\
\hline
\end{tabular}


activity of the examined tin(IV) derivatives is in the following order:

$\mathrm{Ph}_{3} \mathrm{SnL}>\mathrm{Ph}_{2} \mathrm{SnL}>\mathrm{Bz}_{3} \mathrm{SnL}>\mathrm{Bz}_{2} \mathrm{SnL}>\mathrm{Bu}_{3} \mathrm{SnL}>\mathrm{Bu}_{2} \mathrm{SnL}>$ $\mathrm{Me}_{3} \mathrm{SnL}>\mathrm{Et}_{2} \mathrm{SnL}>\mathrm{Me}_{2} \mathrm{SnL}$

Acute toxicity studies. The ALD50 values of the studied diorganotin(IV) derivatives were found to be more than $500 \mathrm{mg} \mathrm{kg}^{-1}$ (the maximum dose tested), whereas those of the triphenyltin(IV) derivatives were $>400 \mathrm{mg} \mathrm{kg}^{-1}$, suggesting the safety margin of these derivatives. Further, it has been observed that the toxicities of these di and triorganotin(IV) complexes are comparable (>500 $\mathrm{mg} \mathrm{kg}^{-1}$ ) with those reported earlier. ${ }^{44}$

Cytostatic activity. Table 8 lists the $\mathrm{IC}_{50}$ values of the compounds, expressed in $\mu \mathrm{M}$, together that of cis$\left[\mathrm{PtCl}_{2}\left(\mathrm{NH}_{3}\right)_{2}\right]$ for comparison. The ethyltin derivatives are less active than the other tin(IV) derivatives. However, all the complexes except ethyl tin complex were less active than the literature reported work with the same cell line. ${ }^{45}$

\section{Acknowledgements}

One of the authors, Dr Amin Badshah is highly thankful to Professor Wrackmeyer B, University of Bayreuth Germany for spectral studies. HEJ Institute of Chemistry, University of Karachi is highly acknowledged for the determination of some of the bioactivities and Associate Professor A.Christofides University of Thessalonki, Greece is highly obliged for providing useful research material.

\section{References}

1. Davies A G.; Organotin Chemistry, VCH Weinheim: Germany, 2004.

2. Gielen, M.; J. Braz Chem. Soc. 2003, 14, 1.

3. Casini, A.; Messori, L.; Orioli, P.; Gielen, M.; Kemmer, M.; Willem, R.; J. Inorg. Biochem. 2001, 85, 297.

4. Gielen, M.; Handlir, K.; Hollein, M.; De, Vos. D.; Met. Based Drugs 2000, 7, 233.

5. Gielen, M.; Biesemans, M.; De, Vos. D.; Willem, R.; J. Inorg. Biochem. 2000, 79, 139.

6. Masood, M.T.; Ali, S.; Danish, M.; Mazhar, M.; Synth. React. Inorg. Met.-Org. Chem. 2002, 32, 9.

7. Chandrasekhar, V.; Nagendran, S.; Baskar, V.; Coord. Chem. Rev. 2002, 235.

8. Casas, T.S.; Castineiras, A.; Haiduc, I.; Sanchez, A.; Semeniuc, R.F.; Sordo J.; Synth. React. Inorg. Met.-Org. Chem. 2001, 31,725 .

9. Wrackmeyer, B.; Vollrath, B. H.; Ali, S.; Inorg. Chim. Acta 1999, 296, 26.
10. Smith, P. J.; Chemistry of Tin, Blackie Academic \& Professional: London, 1998.

11. Gielen, M.; Coord. Chem. Rev. 1996, 151.

12. Gielen, M.; Biesemans, M.; De, Vos. D.; Willem, R.; J. Inorg. Biochem. 2000, 79, 139, and references cited therein.

13. Willem, R.; Bouhdid, A.; Mahieu, B.; Ghys, L.; Biesemans, M.; Tiekink, E.R.T.; D, Vos.De.; Gielen, M.; J. Organomet. Chem. 1997, 15, 531.

14. Gielen, M.; Bouhdid, A.; Kayser, F.; Biesemans, M.; De, Vos. D.; Mahieu, B.; Willem, R.; Appl. Organomet. Chem. 1995, 9 , 251.

15. Tao, J.; Xiao, W.; Yang, Q.; J. Organomet. Chem. 1997, 223, 531.

16. Bonire, J.J.; Fricker, S.P.; J. Inorg. Biochem. 2001, 83, 217.

17. De, Vos. D.; Willem, R.; Gielen, M.; Van, Wingerden. K.E.; Nooter, K.; Met. Based Drugs. 1998, 5, 179.

18. Gielen, M.; Biesemans, M.; De, Vos. D.; Willem, R.; J. Inorg. Biochem. 2000, 79, 139 and references cited therein.

19. Gielen, M.; Dalil, H.; Mahieu, B.; Biesemans, M.; Willem, R.; Appl. Organomet. Chem. 1998, 12, 855.

20. Gielen, M.; J. Braz. Chem. Soc. 2003, 14, 870.

21. Ashfaq, M.; Khan, M.I.; Baloch, M.K.; Malik, A.; J. Organomet. Chem. 2004, 689, 238.

22. Sisdo, K.; Takeda, Y.; Kingawa, Z.; J. Am. Chem. Soc. 1961, 538.

23. Perrin, D.D.; Armengo, W.L.F.; Purification of Laboratory Chemicals, $3^{\text {rd }}$ ed., Pergamon: Oxford, 1988.

24. Rahman, A.; Choudhary, M. I.; Thomsen, W.J.; Bioassay Techniques for Drug Development, Harwood Academic Publishers: The Netherlands, 2001, p. 16.

25. Winter, C.A.; Fisley, E.A.; Nuss G.W.; Proc. Soc. Exp. Biol. N.Y. 1962, 111, 544.

26. Smith, Q.E.; Pharmacological-Screening Test Progress in Medicinal Chemistry, Butter worth: London, 1960.

27. Rossi, C.; Ambrogi, A.; Grandolini, G.; Scarcia, V.; Furlani, A.; J. Pharm. Sci. 1986, 75, 784.

28. Skehan, P.; Storeng, R.; Scudiero, D.; Monks, A.; Mcmahon, J.; Vistica, D.; Warren, J.T.; Bokesch, H.; Kenny, S.; Boyd, M.R.; J Natl. Can. Inst. 1990, 82, 1107.

29. Mahmood, S.; Ali, S.; Bhatti, M. H.; Shahid, K.; Shahzadi, S.; Mazhar, M.; Khan, K. M.; Maharvi, G. M.; J. Chem. Soc. Pak. 2004, 26, 61.

30. Danish, M.; Ali, S.; Shahid, K.; Mazhar, M.; J. Chem. Soc. Pak. 2004, 26, 140 .

31. Lebl, T.; Holecek, J.; Lycka, A.; Sci. Pap. Univ. Pardubice Ser., 1996, A2, 5.

32. Nath, M.; Yadav, R.; Gielen, M.; Dalil, H.; De,Vos. D.; Eng, G.; Appl. Organomet. Chem. 1997, 11, 727.

33. Nath, M.; Yadav, R.; Bull. Chem. Soc. Jpn. 1997, 70, 1331; ibdem, 1998, 71, 1355. 
34. Baul, T. S. B.; Dhar, S.; Rivarola, E.; Smith, F. E.; Butcher, R.; Song, X.; McCain, M.; Eng G.; Appl. Organomet. Chem. 2003, 17, 261 .

35. Camacho, C.C.; De, Vos. D.; Mahieu, B.; Gielen, M.; Kemmer, M.; Biesemans, M.; Willem, R.; Main Group Metal Chem. 2000, 23, 433.

36. Wrackmeyer, B.; Ali, S.; Storch, W.; Vosteen, M.; Z. Naturforsch. 1999, 54b, 1165.

37. Wrackmeyer, B.; Chem. Br. 1990, 48.

38. Eng, G.; Song, X.; Duong, Q.; Strickman, D.; Glass, J.; May, L.; Appl. Organomet. Chem. 2003, 17,218.

39. Nath, M.; Pokharia, S.; Eng, G.; Song, X.; J. Organometal. Chem. 2003, 669, 109.

40. Casas, J.S.; Garcia, Martinez. E.; Jorge, M. L.; Russo, U.; Sanchez, A.; Gonzales, A.; Seoane, R.; Sordo, J.; J. Appl. Organomet. Chem. 2001, 15, 204.
41. Willem, R.; Bouhdid, A.; Mahieu, B.; Ghys, L.; Biesemans, M.; Tiekink, ERT.; De, Vos. D.; Gielen, M.; J. Organomet. Chem. 1997, 151, 531.

42. Choudhary M. A.; Mazhar M.; Ali, S.; Song, X.; Eng, G.; Metal-Based Drugs 2002, 8, 275.

43. Barbiere, R.; Huber, F.; Pellerito, L.; Ruisi, G.; Silverstri, A. In Chemsitry of Tin; Smith, P.J., ed., Blackie Academic \& Professional: Glasgow, 1997, p. 496

44. Nath, M.; Yadav, R.; Eng, G.; Nguyen, T.T.; Kumar, A.; J. Organomet. Chem. 1999, 577, 1.

45. Alvarez-Boo, P.; Casas, J.S.; Castellano, E.E.; Couce, M.D.; Freijanes, E.; Furlani, A.; Russo, U.; Scarcia, V.; Sordo, J.; Varela, M.; Appl. Organomet. Chem. 2001, 15, 75.

Received: November 10, 2004 Published on the web: June 17, 2005 